\title{
Helicobacter pylori management in primary care
}

\author{
Mario M. D'Elios • Elena Silvestri • \\ Giacomo Emmi $\cdot$ Aija Zilevica $\cdot$ Domenico Prisco
}

Received: 22 July 2011 / Accepted: 10 September 2011/Published online: 22 September 2011

(C) SIMI 2011

Helicobacter pylori is a Gram-negative bacterium that chronically infects the stomach of more than $50 \%$ of the human population, and represents the major cause of gastric cancer, gastric lymphoma, gastric autoimmunity and peptic ulcer diseases [1-4]. The International Agency for Research on Cancer classifies H. pylori as a human carcinogen for distal gastric cancer. Eradicating the bacterium, in high-risk populations, reduces the incidence of gastric cancer [5]. Likewise, antibiotic treatment leads to the regression of gastric MALT lymphoma [2]. H. pylori also contributes to other conditions, such as vitamin B12 and iron deficiencies, idiopathic thrombocytic purpura, and growth retardation in children [6].

Current guidelines indicate that the eradication of H. pylori infection is considered mandatory in patients with peptic ulcer and gastric malignancies, such as gastric adenocarcinoma and MALT lymphoma [6, 7]. Furthermore, it is recommended in patients with non-ulcer dyspepsia, especially in those with the evidence of macroscopic or microscopic mucosal abnormalities (erosions, intestinal metaplasia, atrophy), naïve non-steroidal anti-inflammatory drugs (NSAIDs) users, chronic NSAIDs users, first-degree relatives of gastric cancer patients as well as in unexplained

M. M. D’Elios · E. Silvestri - G. Emmi - D. Prisco

PatologiaMedica, AOU Careggi, Largo Brambilla 3,

50134 Florence, Italy

M. M. D'Elios ( $\square)$

Department of Internal Medicine, University of Florence,

viale Morgagni 85, 50134 Florence, Italy

e-mail: delios@unifi.it

A. Zilevica

Clinical Microbiology, University of Latvia,

1050 Rīga LV, Latvia iron deficiency anaemia, and idiopathic thrombocytopenic purpura. Low-dose aspirin (ASA) therapy is widely used in primary care because of the proved efficacy in both primary and secondary prevention of cardiovascular events [8]. A synergistic interaction between $H$. pylori infection and NSAIDs has been extensively documented although the benefits of $H$. pylori eradication in NSAIDs users are conflicting [6, 9-11]. H. pylori has been shown to increase, by almost seven times, the risk of upper gastrointestinal complications in chronic NSAIDs users [12, 13]. The relationship between $H$. pylori infection and NSAIDs in gastroduodenal pathology is complex. Since both NSAIDs and $H$. pylori can cause peptic ulcers, $H$. pylori eradication can only be expected to prevent the recurrence of $H$. pylori ulcers, and while it may also reduce the incidence of ulcers among those with both $H$. pylori and NSAID use, the effects will vary depending on the proportion with real $H$. pylori ulcers in the population studied [6].

Zullo et al. [14] designed a very interesting study (reported in the current issue) to assess the management of H. pylori infection in a very large cohort of chronic NSAID users in primary care clinical settings. $H$. pylori was being used only in a minority (less than 20\%) of primary care patients receiving chronic NSAID therapy. H. pylori was eventually cured in two-third of the infected cases. The low alertness towards such $H$. pylori infection in these patients suggests a need for prompt implementation of current guidelines. Furthermore, the results obtained by Zullo et al. [14], other large meta-analysis studies, strongly support the concept that patients requiring long-term NSAIDs/ASA therapy should be tested and cured of the infection [9, 14, 15] because the cure of $H$. pylori infection contributes to the reduction of potential life-threatening gastrointestinal critical events (such as gastroduodenal bleeding) in primary care unstable patients. 


\section{Conflict of interest None.}

\section{References}

1. Warren JR, Marshall BJ (1983) Unidentified curved bacilli in the stomach of patients with gastritis and peptic ulcer ulceration. Lancet i:1273-1275

2. Wotherspoon AC, Doglioni C, Diss TC et al (1993) Regression of primary low-grade B-cell gastric lymphoma of mucosa-associated lymphoid tissue type after eradication of Helicobacter pylori. Lancet 342:575-577

3. D'Elios MM, Amedei A, Manghetti et al (1999) Impaired T-cell regulation of B-cell growth in Helicobacter pylori-related gastric low-grade MALT lymphoma. Gastroenterology 117:11051112

4. D'Elios MM, Appelmelk BJ, Amedei A et al (2004) Gastric autoimmunity: the role of Helicobacter pylori and molecular mimicry. Trends Mol Med 7:316-323

5. (1994) Schistosomes, liver flukes and Helicobacter pylori. IARC Working Group on the evaluation of carcinogenic risks to humans. Lyon, 7-14 June 1994, IARC Monograph Eval Carcinog Risks Hum 61:1-241

6. Malfertheiner P, Megraud F, O'Morain C et al (2007) Current concepts in the management of Helicobacter pylori infection: the Maastricht III consensus report: Gut 56:772-781

7. Costa F, D'Elios MM (2010) Management of Helicobacter pylori infection. Expert Rev Anti Infect Ther 8:887-892
8. Mahe I, Leizorovicz A, Caulin C et al (2003) Aspirin for the prevention of cardiovascular events in the elderly. Drugs Aging 20:999-1010

9. Vergara M, Catalan M, Gisbert JP et al (2005) Meta-analysis: role of Helicobacter pylori eradication in the prevention of pepticulcer in NSAID users. Aliment Pharmacol Ther 21:1411-1418

10. Sung JJY (2004) Should we eradicate Helicobacter pylori in nonsteroidal anti-inflammatory drug users? Aliment Pharmacol Ther 20(Suppl 2):65-70

11. Salih BA, Abasiyanik MF, Bayyurt N et al (2007) H. pylori infection and other risk factors associated with peptic ulcers in Turkish patients:a retrospective study. World J Gastroenterol 13:3245-3248

12. Huang JQ, Sridhar S, Hunt RH (2002) Role of Helicobacter pylori infection and non-steroidal anti-inflammatory drugs in peptic ulcer disease: a meta-analysis. Lancet 359:14-22

13. Graham DY, Chan FKL (2008) NSAIDs, risks, and gastroprotective strategies: current status and future. Gastroenterology 134:1240-1257

14. Zullo A, Hassan C, Oliveti D et al (2011) Helicobacter pylori management in non-steroidal anti-inflammatory drug therapy patients in primary care Intern Emerg Med. doi:10.1007/s11739011-0578-7

15. Hunt R, Bazzoli F (2004) Review article: should NSAID/lowdose aspirin takers be tested routinely for $H$. pylori infection and treated if positive? Implications for primary risk of ulcer and ulcer relapse after initial healing. Aliment Pharmacol Ther 19(Suppl 1):9-16 